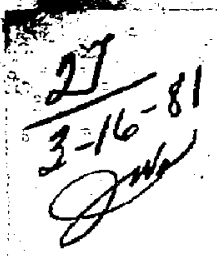

\title{
MASTER
}

(1)

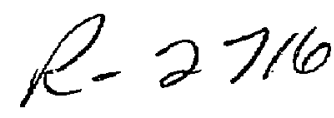

UCTD- 18956

\section{TECHNICAL EVALUATION OT THE SUSCEPTIBILITY OF SAFETY-RELATED SYSTEMS TO FLOODING CAUSED BY \\ THE FAILURE OF NON-CATEGORY I SYSTEHS FOR THE \\ YANKEE ROHE NUCLEAR POWER STATION}

\author{
A. C. Epps
}

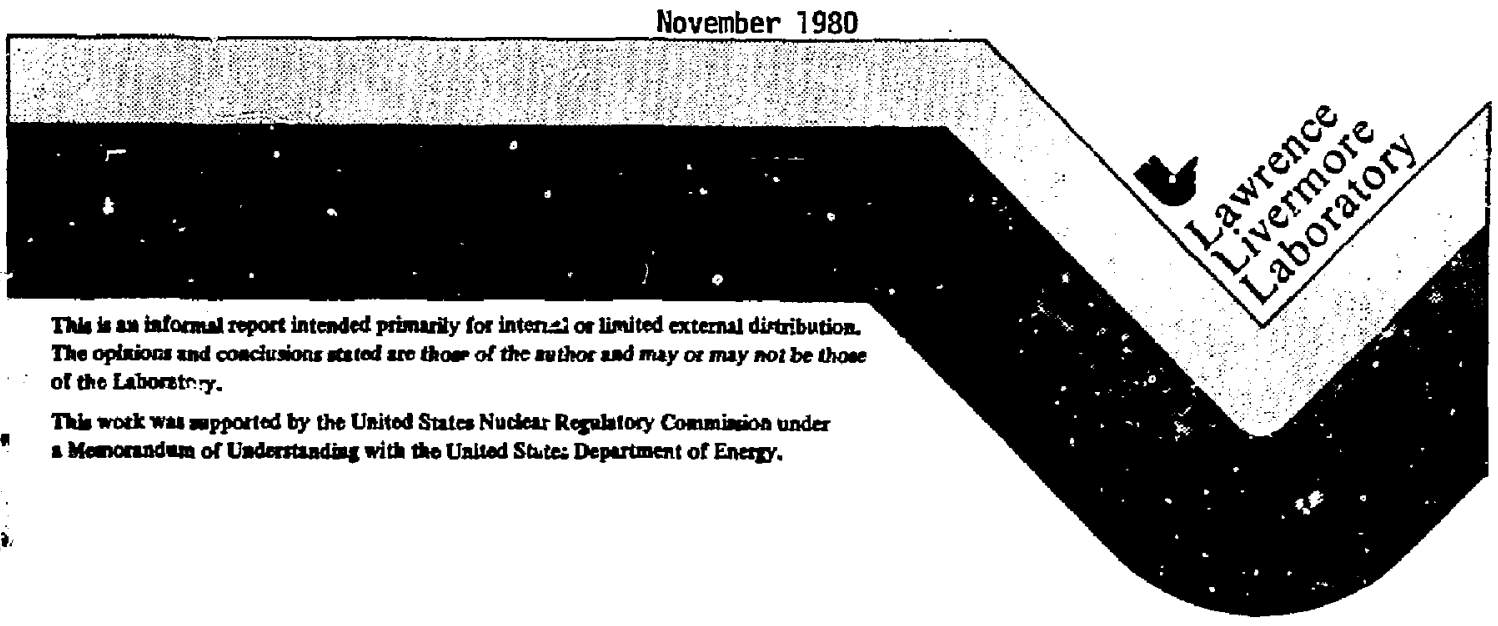

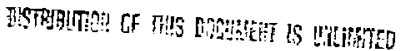




\section{ABSTRACT}

This report documents the technical evaluation of the Maine Yankee Atomic Power Station. The purpose of this evaluation was to determine whether the failure of any non-Class I (seismic) equipment could re: it in a condition, such as flooding, that might adversely affect the jerformance of the safety-related equipment required for the safe shutdown of the facility, or to mitigate the consequences of an accident. Criteria deve oped by the U.S. Nuclear Regulatory Comission were used to evaluate the acceptability of the existing protectior. system as well as measures taken by Maine Yankee Atomic Power Company (MYAPC) to minimize the danger of flooding ind to protect safety-related equipment.

Based on the information supplied, we conclude that the lic nsee, Maine Yankee Atomic Power Company (MYAPC), has demonstrated in its analy. is that the Maine Yankee Atomic Power Station has the capacity and capability to manage and mitigate any single incident, such as flooding fror a non-Class I system component or pipe, so that this flooding will not prevent a safe shutdown of the facility.

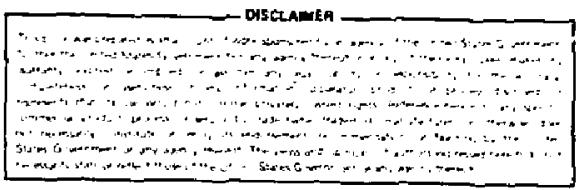




\section{FOREWORD}

This report is supplied as part of the Selected Electrical, Instrumentation and Controi Systems Issues (SEICSI) Program being conducted for the U.S. Nuclear Regulatory Commission (NRC), Office of Nuclear Reactor Regulation, Division of Operating Reactors, by the Lawrence Livermore National Laboratory, Nuclear Systems Safety Program.

The NRC work is funded under the authorization entitled "Electrical, Instrumentation and Control System Support", B\&R 201904 031. FIN A-0231. 
Abstract ............................. i i

Foreword .................. v

1. Introduction ................. I

2. Evaluation ................ 3

2.1 General Considerations ........... 3

2.2 Turbine Building ............ 3

2.3 Primary Auxiliary Building ......... 5

2.4 Diesel Generator Building .......... 6

2.5 Circulating Water Pump House .......... 7

2.6 Waste Disposal Building .......... 8

3. Conc ius ions . . . . . . . . . . . . . . . g

4. Referemces ................. 10

Appendix A .................... 11

Appendix B .................. 13

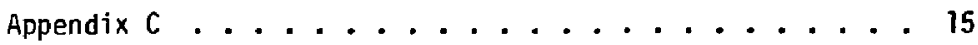


Brank

-viii - 
TECHNICAL EVALUATION OF THE SUSCEPTIBILITY OF

SAFETY-RELATED SYSTEMS TO FLOODING CAUSED BY

THE FAILURE OF NON-CATEGORY I SYSTEMS FOR THE YANKEE ROWE NUCLEAR POWER STATION

\section{INTRODUCTION}

By letter to the Yankee Atomic Electric Company (YAEC) dated August 8, 1972. [Ref. 1], the U.S, Nuc lear Regulatory Commiss ion (NRC) requested YAEC to review the Yankee Rowe Nuclear Power Station to determine whether the failure of any non-Class I (seismic) equipment, farticularly in the circulating water system, could riult in a condition such as flooding that might adversely affect shutdown of the facility or which might be required to limit the consequences of an accident.

By letter to the NRC dated September B, 1972, [R: $f$, 2] YAEC responded to the orignal NRC requirements. NRC requested additional informat ion from YAEC by letters [Refs. $3 \& 7$ ]. YAEC responded to these requests by various letters, [Refs. 4,5,6 and 8]. In their letters YAEC identified critical areas $0^{\prime}$ their plant and gave descriptions of various plant changes that they proposed, to mitigate the effects of some non-Class I system failures on safety-related equipment.

On April 12, 1973, NRC originated a memorandum which outlined the guidelines to be used in evaluating the resprnses from various 1 icensees. These guidelines are provided as Appendix $B$ to this report.

The purpose of this techrical evaluation is to determine, on the bas is of the information provided, whether the licensee's response and equipment/plant modifications are deemed to be adequate to mitigate the effects of flooding on safety-related equipment important to a safe shutdown of the facility.

During the period from August 1972 until November 1975, three separate reviews of the Yankee Rowe facility were conducted by Yankee Atomic Electric Company (YAEC). Initially, at the request of the U. S. Nuc lear Regulatory Commission (NRC), [Ref. 1], YAEC responded [Ref. 2] in gener'l terms stating that the circulating water systen would not produce sufficient flooding to affect the operation of the engineered safety systems, nor would such an occurrence result in common mode failure of redundant safety-related equipment. 
On December 16, 1974, the NRC [Ref. 3] requested additional evaluation on a more detailed basis and submitted a guide for such an evaluation of the Yankee Rowe station. YAEC respoinded on January 20, 1975, [Ref. 4] and again on February 14, 1975, [Ref. 5] to th is request. These responses identified certain areas in the facility that might be vulnerable to flooding which might affect the safety-related systems necessary for safe shutdown of the facility. YAEC also outlined certain modifications that they planned to make to their facility co mitigate the effects of any flooding due to a falure of non-Class 1 system component.

The NRC requested further amplifying information on 0ctober 8, 1975, [Ref. 7] in the form of five detailed questions. YAEC responded on November 25, 1975, [Ref, 8] to all questions.

The various sources of potential flocding identified by YAEC and the affected safety-related equipment, are discussed in sections 2.2 and 2.3. Sections $2.2,2.3$, and 2.4 provide an evaluation of existing protection as well as measures proposed and made by YAEC to minimize the danger of flooding of safety-related equipment. 


\section{EVALUATION}

\subsection{GENERAL CONSIDERATIONS}

The Yankee Rowe Nuclear Power Station was not designed to the seismic criteria now in effect, consequently the piping systems are classified as safety-related or non-safety-related rather than by a seismic category.

All of the applicable non-safety related systems in Reference [3] were included in the licensee's investigation. The licensee has also included an analysis of the vulnerability to flooding of all Class $1 E$ equipment required for a safe shutdown.

The worst case rupture of any piping would be that of the circulating water system which does not have flow reversing valves. The expansion joints in this system are located at ground level in the Turbine Building.

The licensee found no scenario whith would result in common mode faiture of redundant safety-related systen equipment.

The sources of potential flooding at the Yankee Rowe plant that were analyzed were as follows:

$\begin{array}{ll}\text { Service Water } & \text { Drains } \\ \text { Condensate } & \text { Heating Boiler Condensate } \\ \text { Feerwater } & \text { Make-up water } \\ \text { Reactor Building Cooling Water } & \text { Potable water } \\ \text { Circulating Water } & \text { Fire Protection Water } \\ \text { Demineralized Water } & \end{array}$

\subsection{TURBINE BUILDING}

\subsubsection{Safety-Related Equipment Vulnerable to Flooding}

The safety-related equipment in the Turbine Building that is of coniern in a safe shutdown of the plant, are the control and instrumentation systell in the Control Room and the control relays and equipment in the Switchgear Ropm. 


\subsubsection{Sources of Flooding}

The mail sources of flooding in the Turbine Building are the condersate, the feedwater, and the circulating water systems.

Flooding caused by failure of the circulating water line expansion joint will envelope the flooding from the condensate or feedwater lines.

\subsubsection{Systems and/or Merasures to Mitigate the Effects of Flooding}

The Turbine Building contains the Switchgear Room/Battery Rosins and the Contral Room at elevated leveis. The Snitchgear. Room elevation (1037'3") is 15 feat above the ground level of the Turbine Building and the Control Room

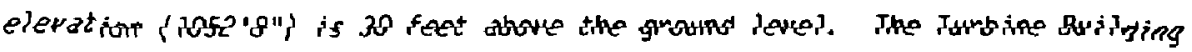
at ground elevation $\left(1022^{\prime} 8^{\prime \prime}\right)$ is a large open area with three large roll-up doors to the outside, and a number of pedestrian doors opening to the outside and other areas of the plant. Major flooding resulting from failure of the circulating water piping expansion joints would be readily cetected by the Turbine Room operator whose station is at the 1022. level in the Turbins Building. The flooding of non-safety related equipment at ground level in the Turbine Building would result in equipment trips, also alerting the operator. The various outside doors to the Turbine Building will fail if water builds up to three or four feet. The operator, in response to operating procedure OP-3016, "In-Plant Flooding Conditions", will open the three large overhsad doors and trip the circulating pump which is the source of the flooding. These factors preclude the flooding from reaching a depth (15') where the switchgear would be threatened.

The turbine driven auxiliary feed pump is located in the auxiliary boiler room which is separated from the Turbine Hall by a closed fire door.

The water inventory in the steam generator can be maintained by the auxitiary feed pump or one of three charging pumps located in the Primary Auxiliary Building. The electric driven main feed pumps can be used as long as off-site power is available. 


\subsubsection{Conclusions}

We conclude that the system features and administrative procedures described above are adequate to prevent flooding of safety-related equifment in the Turbine Building, necessary for a safe shutdnwn of the plant.

\subsection{PRIMARY AUXILIARY BUILDING}

\subsubsection{Safety-Related Equipment Vulnei able to Flooding}

The Primary Auxiliary Building contains Motor Control Center 4, which if flooded would cause failure of charging and purification pumps which are requires for heat removal and long term recirculation phases of a shutdown.

\section{3 .2 5ources of Flooding}

Sources of flooding in the Primary Auxiliary Building are service water, companent cooling water, demineralized water, heating system and condensate which are routed through the lower level of the building. A rupture of any of these systems, which resulted in a water depth in excess of one foot, could flood out Motor Control Center 4 and prevent operation of the charging and purification pumps which are needed for heat removal and post LOCA retirculation.

\subsubsection{Systems anil/cr Measures to Mitigate the Effects of Flooding}

The Licensee has provided sufficient openings at the grcund level in this building to prevent flooding of the motor control center due to any anticipoted event. An opening $5^{\prime}$ 'wide by $1^{\prime}$ 'high was made at the bottom of the double door in the north wall. Three additional openings 1 ' by 1 ' were provided at ground level along the north wall. The licensee has also provided redundant level switches in the floor sump of the Primary Auxiliary Building which initiate alarms in the control Room to alert the operators of any flooding at this location. 


\subsubsection{Conc lusions}

We conclude that the above described features in the Primary Auxiliary Building and the licensee's adninstrative procedures are adequate to mitigate the effects of flooding of the safety-related equipment required for a safe shutoown of the plant.

\subsection{DIESEL GENERATOR BUILOING}

\subsubsection{Safety-Related Equipment Vulnerable to the Effects of Flooding}

The Diesel Generator Building contains the t'sree diesel generators and Ejergency Buses $, 2,2$, and 3 which are required in the event of a loss of offsite power. Also locatad in this building is the safety injection system which is required for both a safe shutdown and a design basis accident (LOCA).

\subsubsection{Sources of Flooding}

No non-safety related piping of any size passes through this building; however, there is a connecting door between this building and the Primary Auxiliary Building which could present a possible source of flooding.

\subsubsection{Systems and/or Measures to Mitigate the Effects of Flooding}

The pctential flooding source in the Diesel Generator Building was through a door between this bulding and the Primary Auxiliary Building. The licensee has provided gasketing around the door between these two buildings to prevent any flow of water from the Primary Auxiliary Building into the Diesel Generator Building. This door is normally kept closed. Alarms are provided to warn the operator in the Control Room when this door is open for more than 15 setonds. 


\subsubsection{Conclusions}

We conclude that the licensee's correct ive measures are adequate to protect the safety-related equipment, located in the Diesel Generator Building, from the effects of flooding.

\subsection{CIRCULATINF: WATER PUMP HOUSE}

\subsubsection{Safety-Related Equipment Vulnerable to the Effects of Flooding}

The Circulating Water Pump House contains the circulating water punps, the service water pumps, the fire water pumps, and their associated piping. Flooding from a rupture in this area might damage the fire system, or sertice water pumps so that they would not be available for use.

\subsubsection{Sources of Flooding}

Sources of flooding are the piping and fittings of the water systens listed above.

\subsubsection{5ystems and/or Measures to Mitigate the Effects of Flooding}

The drain sump in the Circulating Water Pump House is alarmed in the Control Room to alert the operators of any flooding condition in this arei that might affect the service water system. Either of two methods can be

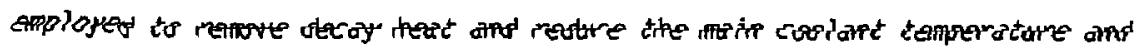
pressure to ambient. The first method is a feed and bieed operation using the Charging and Volume Control system located in the PAB, and the Service Water system which is located in the Circulating water pump house. In the alternate mode, heat can be removed from the primary system by venting the steam generator to atmosphere. Water inventory can be maintained by one of three pumping systems; the steam driven auxiliary feed pump, one of the three charging pumps, or the main feed system if off site power is available. Because there is an alternate method for removing decay heat anc cooling the plant, the service water system is not required for a safe shutdown. 


\subsubsection{Conciusions}

We conclude that the system of alarms in the Circulating Water Pump House is adequate to alert tine operators of impending flooding conditions that might occur in this area. The licensee's analys is also shows that any flooding in this area would not inhibit the capability to the plant of accomplish a safe shutjown.

\subsection{WASTE DISPOSAL BUILDING}

\section{6.l Safety-Related Equipment Vulnerable to the Effects of Flooding}

The Waste Disposal Building contains no equipment required to shut down the plant or any fluid systems of any capacity for flooding.

\subsubsection{Sources of Flooding}

The Waste Disposal Building contains piping for the Fire Water system which could cause some f'ooding

\subsubsection{Systems and/or Measures to Mitigate Effects of Flooding}

The Waste Disposal Building is almost continuously manned and it is located at one of the higher elevations of the plant. Any flood water would be quickly detected and would easily drain away by the operator opening one of the four outside doors.

\subsubsection{Conc lusions}

We conclude that the systems and/or measures described by the 1 icensee are adequate to mitigate the effects of any flooding in the Waste Disposal Building and that any flooding in this area would not inhibit the capability of the plant to accomplish a safe shutdown.

The areas described in the above sections comprise all of the areas which either contain operating fluid systems, or safety-related equipment which would be required for a safe plant shutdown. 


\section{COMCLUSHONS}

Eased on the information supplied by the licensee, we conclude that YAEC has demoustrated in its analysis that the Yankee Nuclear Power Station has the capacity and capability to manage and mitigate any single incident, such as flooding from a non-Class I system component or pipe, so that flooding will not prevent the safe shutdown of the facility.

The licensee has further shown in the analys is that no single failure can cause flooding which would result in comon mode failure of redundant safety-related equipment.

We conclude that YAEC has met all of the requirements of the NRC and that its analysis of the potential flooding conditions and the corrective measures taken at the Yankee Rowe Nuclear Power Station are acceptable. 
[1] Letter from the U.S. Nuc lear Regulatory Commission (NRC) to Yankee Atomic Company (VAEC) dated August \&, 1972

[2] Letter from YAEC to NRC dated September 8, 1972

[3] Letter from NRC to YAEC dated December 16, 1974

[4] Letter from YAEC to NRC dated January 20, 1975

[5] Letter from YAEC to MRC dated February 14, 1975

[6] Letter from YAEC to NRC dated June 4, 1975

[7] Letter from NRC to YAEC dated October 8, 1975

[8] Letter from YAEC to NRC dated November 25, 1975 
UNITED SIATES

ATOMIC ËNERGY COMMISSION

Washington, D.C. 20545

Docket No. $50-29$

August 8, 1972

Yankee Atonic Electric Company

ATTN: Mr. Donald E. Vandenburgh

Vice President

20 Turnpike Road

Westbore, MA 01581

Gentlemen:

\section{FLOODING OF CRITICAL EQUIPMENT}

A failure of an expansion bellows in the circulating water line which serves the main condenser recently occured at Qual-Cities Unit 1. The resultant flooding caused degradation of some of the engineered safety features. Interim corrective action has been taken and more permanent corrective measures are planned at Quad-Cicies 1 and $?$ to prevent recurrence. A copy of the abnormal occurence report filed by Comonweal th Edison for this event is enclosed.

You are requested to review your facilities to determine (1) whether failure of any equipment which does not meet the criteria of Class I seismic construction, particularly the circulating water system, could cause flooding sufficient to adversely affect the performince of engineered safety systems, and (2) whether iailure of any equipment could cause flooding such that comion mode failure of redundait safety related equipment would result. The integrity of barriers to protect critical equipment from flood waters should be assumed only when the barrier meets the seismic requirements of Class I structures. If your review determines that engineered safety features could te so affected, provide your plans and schadule for corrective action togetrer with the justification for continued operation of your facility pending completion of the corrective action. 
The results of your review are requested within sixty days. This information should be provided with one signed orignal and thirty-nine additional copies.

Sincerely,

Donald J. Skovholt

Assistant Director

for Operating Reactors

Directorate of Licensing

Enclosure: CE 1 tr dtd $6 / 17 / 72$

sc to:

C. Duane Blinn, Esouire

Day, Berry \& Howard

Counselors at Law

1 Constitution Plaza

Hartford, Connecticut 05103 
APPENDIK B

NRC GUIDELINES

FOR PROTECTION FROM FLOODING OF EQUIPMENT IMPORTANT TO SAFETY

Licensees are required to investigate their facilites to review the ir designs to assure that equipment important to safety will not be damaged by flooding due to rupture of a non-Class I system component or pipe such that engineered safety features will not perform their design function. No sing1e incident of a non-Class I system component or pipe failure shall prevent safe shutdown of the facility.

Review of responses to the letters should assure that the plancs meet the following guidelines:

1. Separation for redundancy - single failures of non-Class 1 system components or pipes shall not result in loss of a system important to safety. Redundant safety equipment sha?l be separated and protected to assure operabiiity in the event a non-Class I system or component fails.

2. Access doors and alarms - watertight barriers for protection from flooding of equipment important to safety shall have all access doors or hatches fitted with reliable switches and circuits that provide an alarm in the control room when the access is open.

3. Sealed water passages - passages or piping and other penetrations through walls of a room containing equipment mportant to safety shall be sealed against water leakage from any postulated failure of non-Class I water system. The seals shall be designed for the SSE, including seismically induced wave action of water inside the affected compartment during the SSE.

4. Class I watertight structures - walls, doors, panels, or other compartment closures designed to protect equipment important to safety from damage due to flooding from a nol-Class I system rupture shall be designed for the SSE, including seismcally induced wave action sf water ins ide the affected compartment during the SSE. 
5. Water level alarms and trips - rooms containing non-Class I system components and pipes whose rupture couiu resuit in fluod damage to equipment important to safety shall have level alcims and pump trips (where necessary) that alarm in the control room and limit flooding to within the design flood volume. Redundance of switches is required. Critical pump (i.e. high volume flow, such as condenser circulating water pumps) trip circuits should meet IEEE 279 criteria.

6. Class I equipment should be located or protected such that rupture of a non-Class I system connected to a tower containing water or body of water (river, lake, etc.) will not result in failure of the equipment from flooding.

7. The safety analys is shall consider simultaneous loss of offsite power with the rupture of a non-Class I system component or pipe.

The licensees' responses should include a listing of the non-Class I systems considered in their analysis. These should include at least the following systems:

Firewater

Service Water

Condensate

Feedwater

Reactor Building Cooling Water

Turbine Building Cooling Water
Demineralized Water

Drains

Heating Boiler Conderisate

Condenser Circulating Water

Makeup

Potable Water

If the licensee indentifies deficiencies, he should describe interin and final corrective action to be taken and provide a schedule for completion of any required modifications. All corrective action should be completed as expeditiously as is practicable. 
APPENDIX C

UN-DOCKETEO REFERENCE MATERIALS

$9-10-80$

Sent vie TELECOPY to:

John Burdoin, NRC, Washington, D.C.

\section{QUEST IONS FOR YANKEE ROWE PLANT ON FLOOOING}

1. In the Primary Auxi]iary Building ( $F A B$ ), have the water level alarms been installed in the sumps as outlined in Yankee Atomic Electric Company (YAEC) response letter of January 20, 1975?

2. In the $P A B$, have new openings in the sides of the building been provided as outlined in YAEC response of February 14, 1975?

3. In the $P A B$, is the door between the $P A B$ and the Diesel Generator Building (DGB) gasketed to protect against flooding from the $P A B$ as outlined in YAEC response letter of February 14, 1975?

4. Is the door in item 3 above, alarmed in the Control Room?

5. In the $P A B$, low high would water have to be to reach the $480 \mathrm{v} M C C 4$ panel to disable the LP \& HP injection punps?

Is it possible for water to reach that height now?

6. How high would the water have to go to disable the diesel generators in the DGB?

Is it possible for water to reach that height now? 